Journal of MMIJ Vol.123 p.672 - 674(2007)

(C)2007 The Mining and Materials Processing Institute of Japan

Cived 報告

Technical Report

竹原製棟所における貴金属製錬＊

\title{
Improvement of the Precious Metals Process at Takehara Refinery
}

by Yoshihiro MINE

a. Mitsui Mining \& Smelting Co., Ltd Takehara Refinery

(Corresponding author E-mail: y_mine@mitsui-kinzoku.co.jp)

In the precious metals processing line, raw slimes including metals and silver are first decopperized and deselenized, and then converted to noble lead in the melting and settling furnace. Thereafter, it is turned into a crude silver anode by cupellation with the residual lead from the lead refining process. This crude silver is refined by electrolysis to produce electrolytic silver. Electrolytic gold is produced from the crude gold obtained from the sediments of silver electrolysis and part of it is used to produce high purity gold for electronic industry. Aside from these metals, selenium, tellurium, platinum and palladium are recovered.

Recently, We have some improvement in these processes.

KEY WORDS: Precious Metals, Gold, Silver, Deselenized

\section{1. 緒言}

三井金属鉱業株式会社竹原製棟所では，日比共同製錬株式会社 玉野製錬所から送られてくる脱銅スライムを主原料とし，脱セレ ンした後，電気炉にて貴鉛とし，鉛製錬系統の鉛系金銀塊ととも に分銀し，電解により電気銀，電気金を生産している。

\section{2. 最近までの経緯}

\section{$2 \cdot 1$ 設備概要}

製錬各社がスライムからの貴金属回収に湿式処理法を導入して くる中，竹原では従来の乾式法を中心とした精錬法を実施してい

る。Fig. 1 に現在の回収工程フローシートを示す。

竹原製棟所の特徵は，底吹酸化炉 (BBOC) であり，炉底から酸 素を噴出して酸化を促進させる酸化炬である。従来の上吹き酸化 炉より 3，4 倍速く粗銀精製が可能であるため，低コス卜処理と なるだけでなく，採収率アップや増産に大きく寄与して来た。

また，鈶品位の高い残涬を供用できることから，鉛リサイクル 系から貴金属回収寸るときの鉛系金銀塊も処理できている。

$2 \cdot 2$ 最近の処理状況

Fig. 2 にBBOCの構造を, また Table 1 に最近のスライム処理 量を示す。銀生産量のうち約半分は鉛系残留鉛からの回収であり, BBOCでの処理により鉛を含む原料が処理できている。また，原 単位削減についても，酸素吹込久量の見直し，保温加温時間の見 直し等など進めてきている (Fig. 3)。具体的には，酸素吹込み量 を $30 \Rightarrow 20 \mathrm{l} / \mathrm{min}$ に減少させることで反応速度を抑制し, Sb,

* 2007 年 5 月 14 日受付 11 月 12 日受理

1. 普通会員 三井金属鉱業株式会社 竹原製棟所 金属工場

[ 著者連絡先 ] FAX : 0846-22-7460

E-mail :y_mine@mitsui-kinzoku.co.jp

キーワード : 貴金属, 金, 銀, 脱セレン
$\mathrm{Pb}, \mathrm{Bi}$ などの分離性を良くした。また，酸素量減少により BBOC 内面の棟瓦の痛みが抑えられた。

棟瓦材質自体の見直しも実施し，結果として棟瓦寿命延長 (35 $\Rightarrow 50$ バッチ）となった。保温加温用灯油についても，保持温度 を必要以上に上げないよう管理強化し，大幅な削減を実施した。

\section{3. 最近の改善事例}

本報告では，過去 8 年間の諸改善，およびスライム焙焼改善事 例など足元の改善について報告する。

\section{$3 \cdot 1$ 最近の改善事例}

Table 2 に 2005 年度までの諸改善項目を示す。既存の乾式法の

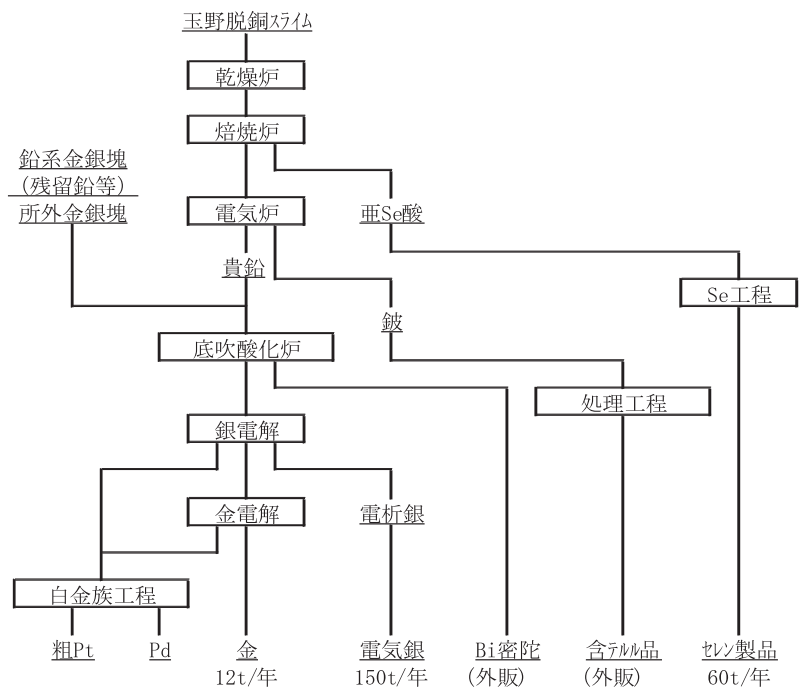

Fig.1 The Precious Metals Processing Line. 


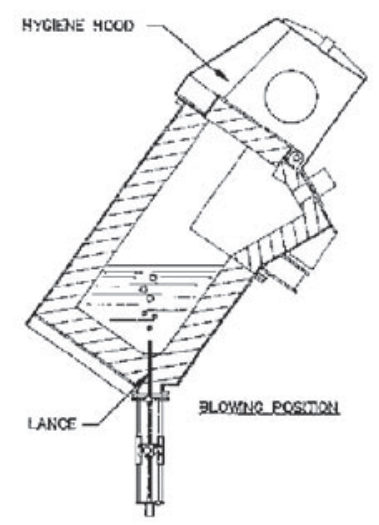

Fig.2 Bottom Blown Oxygen Converter (BBOC).

Table 1 Date of The Slime throughput.

\begin{tabular}{|c|c|c|c|c|c|}
\hline \multirow[b]{3}{*}{ 西暦 } & \multicolumn{2}{|c|}{ 竹原スライム処理関連 } & \multirow[t]{2}{*}{ 単位：kg } & \multirow{2}{*}{\multicolumn{2}{|c|}{$\begin{array}{l}\text { 単位: } t \\
\text { 供用 (単位t) }\end{array}$}} \\
\hline & & 産出 (単位kg) & & & \\
\hline & 金 & 銀 & セレン & スライム & 残留鉛 \\
\hline 2000 & 20.225 & 148,857 & 52.794 & 757 & 326 \\
\hline & & 139,059 & 70,492 & 754 & 313 \\
\hline & 15 & 142,638 & 85,7 & 944 & 295 \\
\hline & 16,2 & 150,504 & 94,904 & 898 & 276 \\
\hline & 13,9 & & 58,470 & 810 & 226 \\
\hline & 13,179 & 171,904 & 50,887 & 765 & 267 \\
\hline
\end{tabular}

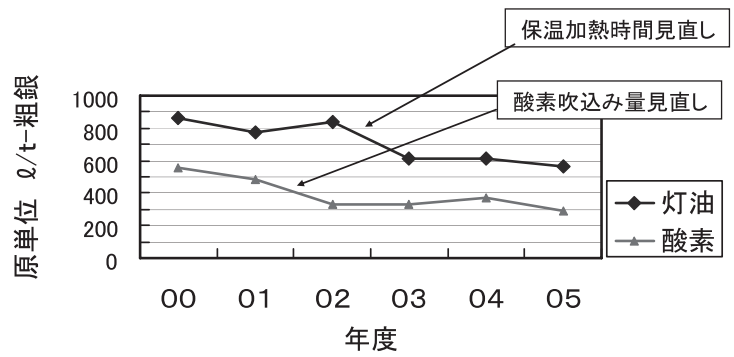

Fig.3 Operating Date of BBOC

改善，更新により，低コスト増処理対応を進めてきた。以降，本 文 3. 2 項以降の改善により, 銀電解は生産量に合わせて $16 \mathrm{t} /$ 月と コンパクトにして移設し，21t/月までの増強スペースを残した。ス ライムの処理能力も $100 \mathrm{t} /$ 月を維持して, Se 焙焼能力強化対策と して導入エアーの熱交換加熱など熱効率の改善を実施して来た。

\section{$3 \cdot 2$ 銀電解設備老朽化更新}

建屋築 65 年を経過しており, 安全対策, コンパクト化による 作業性向上を狙い，2005 年に更新した。析離銀の自動洗浄 ( 昇 降式), 掻落し板の軽量化と FRP 化, 滑りにくい床面等の改善を 織り込んだ。なお, Fig. 4 に示すように, 足元の銀の生産量は増 加してきており, 更なる今後の増産対応スペースや抜き出し自動 化など追加改善できるレイアウトとした。

\section{$3 \cdot 3$ スライムの焙焼改善}

乾式での処理は，コストが安く鉛含有原料も処理できるメリッ トがある。ここ 2 年間で，大幅な投資をすることなく，焙焼キル ンの改善を進めた。具体的には, 廃熱の回収強化, マット等中間 物の別処理, Se 品位に合わせた投入量管理強化などにより, 焙 焼効率向上を進めてきた (Fig. 5)。

その結果, 焙焼した後のスライム中の Se 品位は, 足元では, 0. $5 \%$ ををところまで改善してきた。

\section{3・4 高純度金の改善}

竹原では，電子素材 ( ボンディングワイヤー等) に使用できる
Table 2 Improvement of The Slime treatment

\begin{tabular}{|c|c|}
\hline \multicolumn{2}{|r|}{ 竹原スライム処理特記事項 } \\
\hline 西暦 & 特記事.項 \\
\hline 1998 & 焙焼炬改善 (コンデンサー更新) ・金電解増強 (2.4t/月) \\
\hline 1999 & \\
\hline 2000 & 乾燥キル能力増強（灯油バーナ一設置） \\
\hline 2001 & No. 2 バグ更新 \\
\hline 2002 & \\
\hline 2003 & 銀電解 液清浄部分更新 - 電析銀生産能力増強 \\
\hline 2004 & 焙燒キル排熱熱交換更新 \\
\hline 2005 & 焙焼キルン熱効率改善、煙道更新完了（03〜) \\
\hline
\end{tabular}

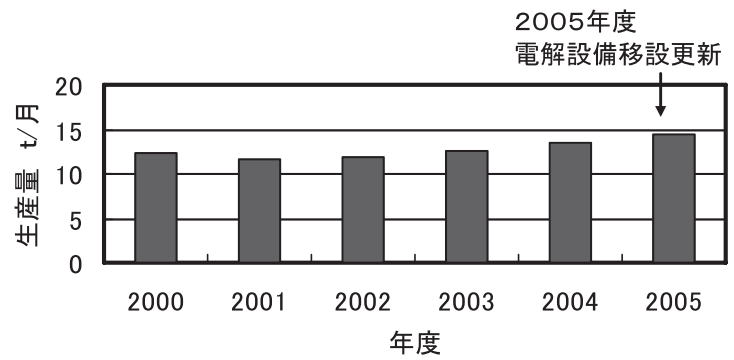

Fig.4 Production of Silver

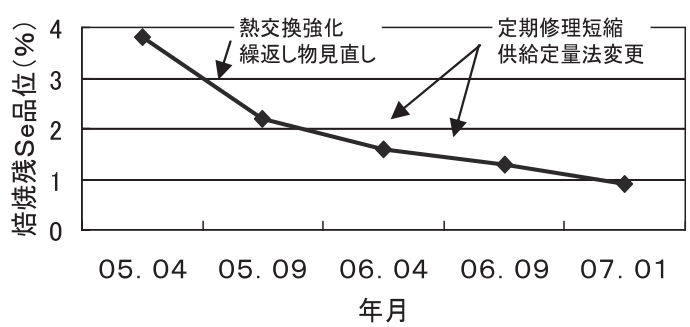

Fig.5 Improvement of The Slime Roasting.

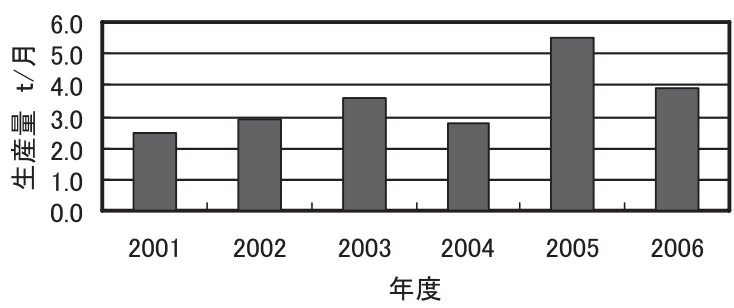

Fig.6 Production of The Distilled Selenium.

高純度金を製造している。製造方法は，5N 以上の高純度金を製 造する一般的な方法 (電解等) であるが，ボンディングワイヤー の用途とする場合，断線しないことが重要となる。

竹原では, 製品分析值で捉えられない微量の成分に対し, ユー ザーと技術検討を進め, 製造方法の改善を加え, 高機能の高純度 金の製造をしている。具体的には，真空溶解による精製，また工 程をクリーンルーム化し, 専用作業服の使用, 空気清浄度の管理, 外気圧との差圧管理などを実施し，断線しにくい高純度金を製造 してきている。

\section{$3 \cdot 5$ 蒸留セレンの改善}

竹原では，電子素材として使用できるセレンも製造している。 ここでも製品分析值で捉えられない微量の成分に対し，ユーザー と技術検討を進め, 製造方法の改善を加え, 高機能の高純度セレ ンの製造をしている。需要も増加傾向となってきた。生産量の推 移をFig. 6 に示す。 


\section{4. 今後の展望}

各社スライムの湿式処理が進められる中，(1)竹原の乾式処理メ リットである鉛含有原料の低コスト処理，(2) Se を含むその他の貴 金属採収率の向上，(3)各製品の電子材料向け用途による品質強化， 等を進め, 竹原におけるスライム処理の改善を進めて行きたい。
5. 結

$\overline{\overline{\bar{一}}}$

竹原の貴金属処理工場の歴史は古く, 昭和 13 年にその操業が 始まる。以降，所先輩方の改善により現在の工場がある。

これまでの諸改善, および今回のまとめと足元の改善に携わっ ていただいた方々に感謝を申し上げたい。 